\title{
The Roles of Extraordinary Beliefs in Consumption Rituals
}

\author{
Cele C. Otnes \\ University of Illinois at Urbana-Champaign \\ Linda Tuncay Zayer \\ Loyola University Chicago, Ituncay@luc.edu \\ Robert Alfonso Arias \\ University of Illinois at Urbana-Champaign \\ Arun Sreekumar \\ University of Illinois at Urbana-Champaign
}

Follow this and additional works at: https://ecommons.luc.edu/business_facpubs

Part of the Business Commons

\section{Recommended Citation}

Otnes, Cele C.; Zayer, Linda Tuncay; Arias, Robert Alfonso; and Sreekumar, Arun. The Roles of Extraordinary Beliefs in Consumption Rituals. Journal of the Association for Consumer Research, 3, 4: 566-581, 2018. Retrieved from Loyola eCommons, School of Business: Faculty Publications and Other Works, http://dx.doi.org/10.1086/699674

This Article is brought to you for free and open access by the Faculty Publications and Other Works by Department at Loyola eCommons. It has been accepted for inclusion in School of Business: Faculty Publications and Other Works by an authorized administrator of Loyola eCommons. For more information, please contact ecommons@luc.edu.

\section{(c) $($ () $\ominus$}

This work is licensed under a Creative Commons Attribution-Noncommercial-No Derivative Works 3.0 License. (C) The Association for Consumer Research 2018 


\title{
The Roles of Extraordinary Beliefs in Consumption Rituals
}

\author{
CELE C. OTNES, LINDA TUNCAY ZAYER, ROBERT ALFONSO ARIAS, AND ARUN SREEKUMAR
}

\begin{abstract}
People often ascribe to extraordinary beliefs (EBs), or those that laws of science cannot explain, or those that may even contradict science. Both the foundational literature in anthropology and recent work in consumer behavior affirm the assumption that rituals — structured, repeated, symbolic, and expressive activities - might be one context where extraordinary beliefs shape consumer experiences. To date, however, little understanding exists regarding the types of EBs that emerge in consumption-ritual contexts, and how they influence ritual participation. We examine over 30 years of articles in top-tier journals to address two questions: (1) Which EBs emerge as salient to consumer rituals? (2) How do EBs shape consumer ritual participation? In doing so, we illuminate the role of 15 EBs organized by four key functions. We reveal important gaps in understanding the interplay between EBs and consumer rituals and offer future research recommendations to address these gaps.
\end{abstract}

onsumer rituals - structured, repeated, symbolic, and expressive activities that leverage goods and services to perform important sociocultural functions (Rook 1985) - are vital contributors to both the world economy and people's life histories. Consider that the global beauty/personal care market, the economic engine behind grooming rituals, is projected to increase from $\$ 432.6$ billion in 2016 to almost $\$ 700$ billion by 2023 (Research and Markets 2017). And although the average cost of weddings in the United States now exceeds $\$ 35,000$ (Seaver 2017), families in India often spend up to $\$ 300,000$ on multiday, community-wide celebrations (Bhatia 2015). Furthermore, as Japanese Christmas celebrations reveal, cultures often adapt imported rituals, harmonizing them with local norms, traditions, and values (Kimura and Belk 2005).

Consumer behavior scholars often assert that personal, family, social, and cultural rituals provide respite from routinized lives and "affirm, evoke, assign, or revise the conventional symbols and meanings of the cultural order" (McCracken 1986, 78). Beliefs in the salience and symbolism of rituals enable them to offer what Driver (1991) describes as three social gifts: providing structure, enhancing community, and offering opportunities for transformation. Even in a world dominated by adherence to scientific procedures and progress, sometimes these beliefs are extraordinary; that is, they transcend or even contradict the natural laws of science (Otis and Alcock 1982).

Anthropological studies of rituals (e.g., Mauss 1950/ 2005; Turner et al. 1966/2017), along with work in consumer research, affirm that extraordinary beliefs (EBs) might be crucial components of ritual contexts. For example, Rook (1985) notes that both cosmological belief systems and nonreligious mystical elements (e.g., superstitions) can infuse and influence consumer rituals. In this article, we address two questions: (1) Which EBs emerge as salient to consumers' ritual experiences? (2) How do EBs shape consumers' ritual participation? In doing so, we offer the following contributions. First, we identify and illuminate 15 salient EBs in consumption-ritual contexts. Second, we present an inductive typology that captures four overriding functions of EBs in these contexts and demonstrate how each EB (with two exceptions) typically serves one of these functions. We also highlight two "uber" EBs that fulfill multiple functions. Although this typology emerges from studies of consumer rituals, we believe its usefulness extends to scholars interested in how EBs shape a wide range of consumer behaviors

Cele C. Otnes (cotnes@illinois.edu), corresponding author, and Anthony J. Petullo, chair of business administration, Department of Business Administration, 330 Wohlers Hall, 1206 S. Sixth St., University of Illinois at Urbana-Champaign, Champaign, IL 61820. Linda Tuncay Zayer (ltuncay@luc.edu), associate professor, Department of Marketing, Quinlan School of Business, Loyola University, Chicago, Illinois. Robert Alfonso Arias (rarias5@illinois.edu), marketing doctoral candidate, Department of Business Administration, University of Illinois at Urbana-Champaign. Arun Sreekumar (aruns2@illinois.edu), marketing doctoral student, Department of Business Administration, University of Illinois at Urbana-Champaign.

JACR, volume 3, number 4. Published online September 10, 2018. http://dx.doi.org/10.1086/699674 (c) 2018 the Association for Consumer Research. All rights reserved. 2378-1815/2018/0304-0025\$10.00 
(e.g., how these influence choice). Third, we offer evidence that illuminates how EBs shape consumers' experiences at different stages of ritual experiences. Finally, we offer future research questions to motivate the study of linkages between EBs and myriad consumption-related topics.

\section{METHOD}

We engaged in a systematic review of ritual scholarship appearing in journals focusing on consumer behavior and marketing topics. To generate our article sample, we first consulted the Scimago Journal Rank (SJR) of all marketing journals. Scimago draws on citation metrics in the SCOPUS database across 313 countries, generating impact factors by considering both article citation counts in journals and journal prestige. To include those articles likely to be the most visible and effective in the field, we retained 12 journals that Scimago identifies with an impact factor of at least 2.5 (Scimago Lab 2018). We acknowledge that many other journals publish high-quality scholarship on ritualistic consumption. We searched for articles in these 12 journals by leveraging three databases (Business Source Complete; Business Source Elite; Business Source Ultimate) in the EBSCO subscription at the first author's university library. We also reviewed articles in $J A C R$, recognizing that this scholarship would be particularly interesting to readers of this special issue. Its recent debut also means Scimago may not yet fully capture its impact.

In our first scrutiny of these journals, we identified articles exploring consumption rituals by conducting a combined keyword text search for "ritual(s)," "consumer," or "consumption," assuming that authors positioning their work within this topic area would use those terms. We excluded articles where the word "ritual" appeared only in references, in lists of phenomena or as mere mentions by authors, and/or as a brand name or proxy variable in experiments. We also eliminated articles that focused on research methods or on organizational (vs. consumer) behavior, as well as book reviews, research curations, rejoinders, and reflections. In addition, we found 42 articles on gift giving in these 12 journals. We excluded these because gift giving typically is embedded within broader rituals, and we wanted to explore how EBs affect rituals at a more holistic level.

We located 65 articles meeting these screening criteria in five of the 12 journals: Journal of the Academy of Marketing Science, Journal of Consumer Psychology, Journal of Consumer Research, Journal of Marketing, and the Journal of Retailing. We included one article from the Journal of the Association for Consumer Research. We then reduced this set to include only articles focusing in whole or in part on consumers' ritual participation - eliminating those that focused solely on marketers' perspectives, that are conceptual, or that explore rituals from consumers' perspectives but that do not contain examples of EBs in consumer excerpts. This process resulted in our final sample of 37 articles (see table 1 ). It is worth noting that no article actually made the linkages between EBs and consumer rituals its focus. Thus, the fact that we find emic examples in over half of the articles we originally sampled supports the salience of the topic.

\section{Coding}

Adhering to Otis and Alcock's (1982) definition of EBs cited above, each coauthor coded a subset of articles for emergent EBs: ritual context, consumers' motivations for ritual engagement, ritual elements, and ritual outcomes. This process helped us gain insights into whether and how EBs shaped consumers' ritual experiences. Our specific units of analysis for the EBs are consumers' own words; that is, emic excerpts from interviews or field notes that capture consumers' verbatim quotes in ritual contexts. These excerpts also contain "negative cases" - that is, consumers' reflections when they did not find support for EBs they expected to be salient.

The author team then discussed, defined, and differentiated the EBs emerging in the excerpts within and across the articles, resolving discrepancies in interpretations by reviewing the excerpts together. This process resulted in the team generating a set of mutually exclusive and collectively exhaustive EBs salient to consumers' ritual experiences. Cycling inductively and iteratively between our sample articles, the literature, and our working manuscript, we then strove to group the EBs into higher-level abstract categories (or tropes; Spiggle 1994), based on their overriding functions within ritual contexts. We found that we could group each EB under one of four tropes that illuminates an overriding function (with two exceptions, as we discuss). Table 2 contains additional excerpts illuminating each trope and EB.

\section{EBS SALIENT TO RITUALISTIC CONSUMPTION}

Our first research question asks the following: "which EBs emerge as salient to consumers' ritual experiences?" We find support for $15 \mathrm{EBs}$, as indicated below.

\section{Connecting EBs}

We define connecting EBs as those primarily enabling consumers to forge or maintain linkages to people, places, or objects when engaging in rituals and that help consumers 
Table 1. Final Article Sample with Emic Examples of Extraordinary Beliefs and Ritualistic Consumption

\begin{tabular}{|c|c|c|}
\hline Author(s) & Article Title & Journal/Date/Vo \\
\hline Arnould & $\begin{array}{l}\text { "Toward a Broadened Theory of Preference Formation and the Diffusion } \\
\text { of Innovations: Cases from Zinder Province, Niger Republic" }\end{array}$ & JCR, 1989, 16 \\
\hline Arnould and Price & "River Magic: Extraordinary Experience and the Extended Service Encounter" & $J C R, 1993,20$ \\
\hline Belk and Costa & "The Mountain Man Myth: A Contemporary Consuming Fantasy" & $J C R, 1998,25$ \\
\hline Belk, Wallendorf, and Sherry Jr. & "The Sacred and Profane in Consumer Behavior: Theodicy on the Odyssey" & $J C R, 1989,16$ \\
\hline Beverland and Farrelly & $\begin{array}{l}\text { "The Quest for Authenticity in Consumption: Consumers' Purposive Choice } \\
\text { of Authentic Cues to Shape Experienced Outcomes" }\end{array}$ & $J C R, 2020,36$ \\
\hline Bonsu and Belk & $\begin{array}{l}\text { "Do Not Go Cheaply into That Good Night: Death-Ritual Consumption } \\
\text { in Asante, Ghana" }\end{array}$ & $J C R, 2003,30$ \\
\hline Bradford and Sherry Jr. & "Domesticating Public Space through Ritual: Tailgating as Vestaval" & $J C R, 2015,42$ \\
\hline Canniford and Shankar & $\begin{array}{l}\text { "Purifying Practices: How Consumers Assemble Romantic Experiences } \\
\text { of Nature" }\end{array}$ & JCR, 2013, 39 \\
\hline Celsi, Rose, and Leigh & "An Exploration of High-Risk Leisure Consumption through Skydiving" & $J C R, 1993,20$ \\
\hline Decrop and Derbaix & "Pride in Contemporary Sport Consumption: A Marketing Perspective" & JAMS, 2010, 38 \\
\hline Diamond, Sherry Jr., et al. & $\begin{array}{l}\text { "American Girl and the Brand Gestalt: Closing the Loop on Sociocultural } \\
\text { Branding Research" }\end{array}$ & $J M, 2009,73$ \\
\hline Epp and Price & $\begin{array}{l}\text { "The Storied Life of Singularized Objects: Forces of Agency and Network } \\
\text { Transformation" }\end{array}$ & JCR, 2010, 36 \\
\hline Fernandez and Lastovicka & "Making Magic: Fetishes in Contemporary Consumption" & $J C R, 2011,38$ \\
\hline Fischer, Otnes, and Tuncay & $\begin{array}{l}\text { "Pursuing Parenthood: Integrating Cultural and Cognitive Perspectives } \\
\text { on Persistent Goal Striving" }\end{array}$ & JCR, 2007, 34 \\
\hline Goulding, Shankar, and Canniford & "The Marketplace Management of Illicit Pleasure" & $J C R, 2009,35$ \\
\hline Hirschman & "Consumers and Their Animal Companions" & $J C R, 1994,20$ \\
\hline Kozinets & $\begin{array}{l}\text { "Can Consumers Escape the Market? Emancipatory Illuminations from } \\
\text { Burning Man" }\end{array}$ & $J C R, 2002,29$ \\
\hline Leigh, Peters, and Shelton & $\begin{array}{l}\text { "The Consumer Quest for Authenticity: The Multiplicity of Meanings within } \\
\text { the MG Subculture of Consumption" }\end{array}$ & JAMS, 2006, 34 \\
\hline Martin & $\begin{array}{l}\text { "Using the Imagination: Consumer Evoking and Thematizing of the } \\
\text { Fantastic Imaginary" }\end{array}$ & $J C R, 2004,31$ \\
\hline McAlexander et al. & "The Marketization of Religion: Field, Capital, and Consumer Identity" & $J C R, 2014,41$ \\
\hline Muñiz Jr., and O'Guinn & "Brand Community" & $J C R, 2001,27$ \\
\hline Muñiz Jr., and Schau & "Religiosity in the Abandoned Apple Newton Brand Community" & $J C R, 2005,31$ \\
\hline Nguyen and Belk & $\begin{array}{l}\text { "Harmonization Processes and Relational Meanings in Constructing } \\
\text { Asian Weddings" }\end{array}$ & $J C R, 2013,40$ \\
\hline O’Guinn and Belk & "Heaven on Earth: Consumption at Heritage Village, USA" & $J C R, 1989,16$ \\
\hline Otnes, Lowrey, and Shrum & "Toward an Understanding of Consumer Ambivalence" & $J C R, 1997,24$ \\
\hline Peñaloza & $\begin{array}{l}\text { "The Commodification of the American West: Marketers' Production } \\
\text { of Cultural Meanings at the Trade Show" }\end{array}$ & $J M, 2000,64$ \\
\hline Rook & "The Ritual Dimension of Consumer Behavior" & $J C R, 1985,12$ \\
\hline Russell and Schau & $\begin{array}{l}\text { "When Narrative Brands End: The Impact of Narrative Closure and } \\
\text { Consumption Sociality on Loss Accommodation" }\end{array}$ & $J C R, 2014,40$ \\
\hline Schau, Muñiz Jr., and Arnould & "How Brand Community Practices Create Value" & $J M, 2009,73$ \\
\hline Schouten & $\begin{array}{l}\text { "Selves in Transition: Symbolic Consumption in Personal Rites of Passage } \\
\text { and Identity Reconstruction" }\end{array}$ & $J C R, 1991,17$ \\
\hline Scott, Cayla, and Cova & "Selling Pain to the Saturated Self" & $J C R, 2017,44$ \\
\hline Sezer et al. & "Family Rituals Improve the Holidays" & $J A C R, 2016,1$ \\
\hline Sherry Jr. & "A Sociocultural Analysis of a Midwestern American Flea Market" & $J C R, 1990,17$ \\
\hline St. James, Handelman, and Taylor & "Magical Thinking and Consumer Coping" & $J C R, 2011,38$ \\
\hline
\end{tabular}


Table 1 (Continued)

\begin{tabular}{ll}
\hline Author(s) & Article Title \\
\hline Üstüner and Holt & $\begin{array}{c}\text { Mominated Consumer Acculturation: The Social Construction of Poor } \\
\text { "Status, Caste, and Market in a Changing Indian Village" } \\
\text { Vikas, Varman, and Belk }\end{array}$ \\
$\begin{array}{l}\text { Wallendorf and Arnould } \\
\text { Py Favorite Things": A Cross-Cultural Inquiry into Object Attachment, }\end{array}$ \\
\hline
\end{tabular}

build empathy or foster intimacy with goods and services. Our analysis supports one EB that solely exhibits this function, although obviously this trope is salient in the two uber EBs as well.

Nostalgia. Holbrook (1993, 245) observes that nostalgic beliefs reflect people's perceptions that "things were better then ... than now." Nostalgic beliefs qualify as extraordinary because consumers do not rely on accurate memories of an event but on "memory-laden possessions . . . that evoke affective experiential knowledge of what the event was like ... [and that] may in fact be distorted factually" (Belk 1991, 29). Consumer rituals often evoke nostalgia, because artifacts, roles, and places "concentrate time in space, allowing [those] present to connect with [those] past" (Gillis 1997, 93). Nostalgia permeates microrituals (e.g., family events), as well as culturally pervasive celebrations. Another reason nostalgic beliefs exist in the realm of nonscientific thought is that people's remembrances of the past may draw upon events they never experience or that occur prior to their own lives (Holbrook 1993). One informant in Peñaloza's (2000) study of the National Western Stock Show and Rodeo remarks on how nostalgia permeates visitors' experiences: "The show is as close [to the West] as they'll get. Here they get to associate and reminisce about what no longer is and will never be again" (Peñaloza 2000, 96). Importantly, people may even recognize the EB of "anticipated nostalgia"; that is, a time in the future when they will be nostalgic about participating in past consumer rituals. One soccer fan notes after participating in songs and other activities at a match: "Later, when I'll get old, I'll have some good times to remember . . . what we've done" (Decrop and Derbaix 2010, 598).

\section{Controlling EBs}

The primary function of controlling EBs is to enable consumers to reduce uncertainty - specifically, to help them leverage their own or others' agency to shape ritual outcomes.
We identify "faith," "self-transformation," "superstition," and "taboo" as controlling EBs.

Faith. Faith is a "firm belief in something for which there is no proof" (Merriam-Webster 2018). Although religious systems have faith at their core, not all faith beliefs stem from a religion. In an increasingly secular world, consumers may increasingly place their faith in experts (e.g., river-rafting guides; Arnould and Price 1993) and technology (e.g., medical treatments; Fischer, Otnes, and Tuncay 2007) than in cosmological belief systems We find that in ritual contexts, people often exhibit faith in situations involving high-risk consumption, where outcomes can be uncertain or even disastrous. For example, Celsi, Rose, and Leigh's (1993) skydiving informants attempt to exert control over this dangerous activity by expressing faith in their equipment, attributing others' skydiving accidents not to equipment failures but to human error. They aver that because they are facile with superior equipment, they have faith that they will be immune from disastrous outcomes.

Self-Transformation. Transformation is defined as the "operation of changing" (Merriam-Webster 2018); thus, the EB of self-transformation reflects people's beliefs that they can change themselves, despite the lack of compelling evidence - or the presence of contradictory evidence - that such changes will occur. Our findings in ritual contexts affirm McCracken's $(2008,294)$ statement that people often engage in "restless, sometimes reckless pursuit of options and an abrogation of rights of self-creation, self-approval and self-government." Moreover, people may evoke the EB of self-transformation prior to engaging in rituals, or after the ritual has worked its magic - often to participants' surprise. Once again, however, they may adhere to this EB even if evidence contradicts its validity. The most transparent example in our data set involves participants in the weeklong Burning Man event. Many profess that immersing themselves into a festival based on bartering and creative display transforms them (at least temporarily) into occupants of a 


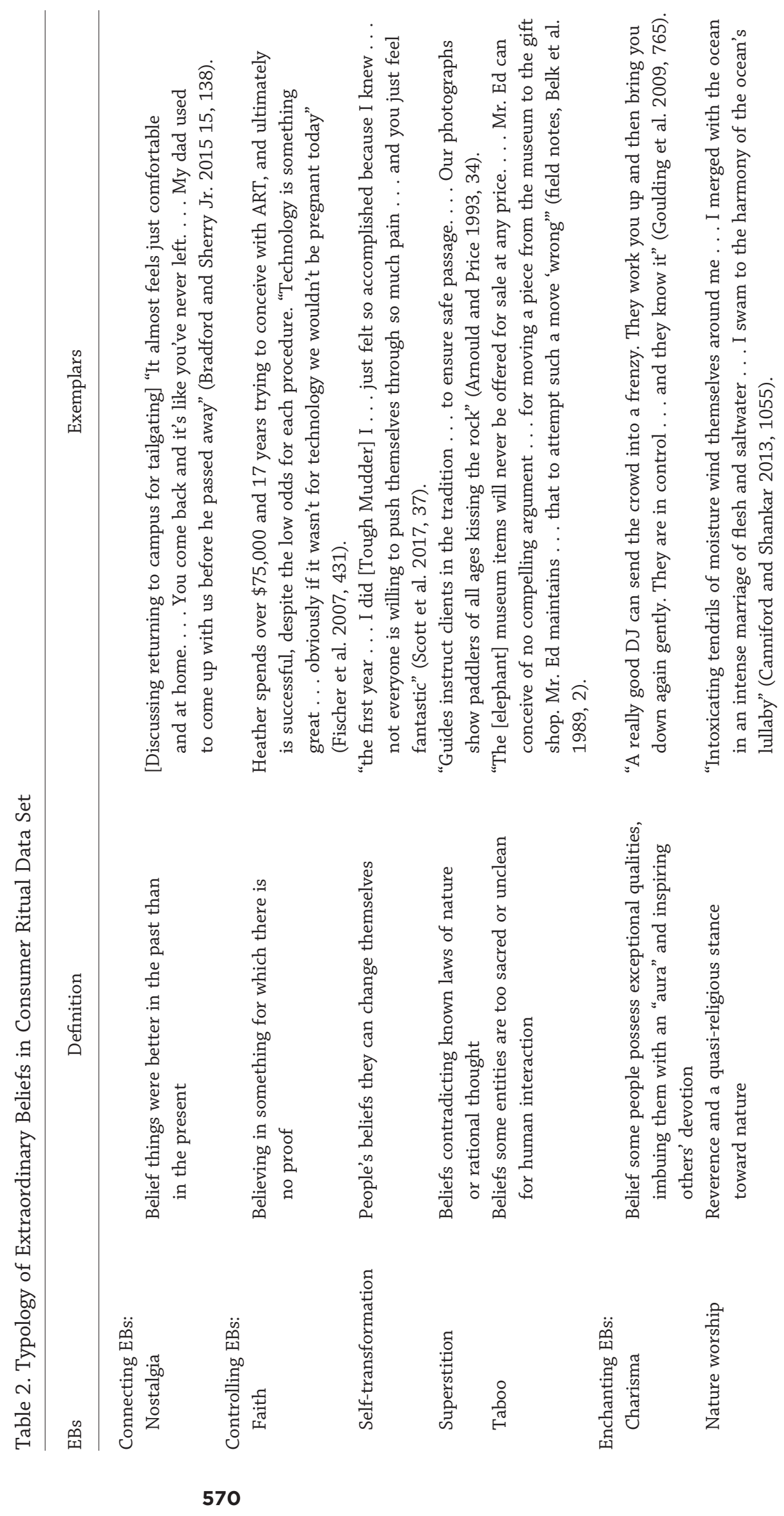

This content downloaded from 129.089.031.133 on December 18, 2018 16:09:51 PM 


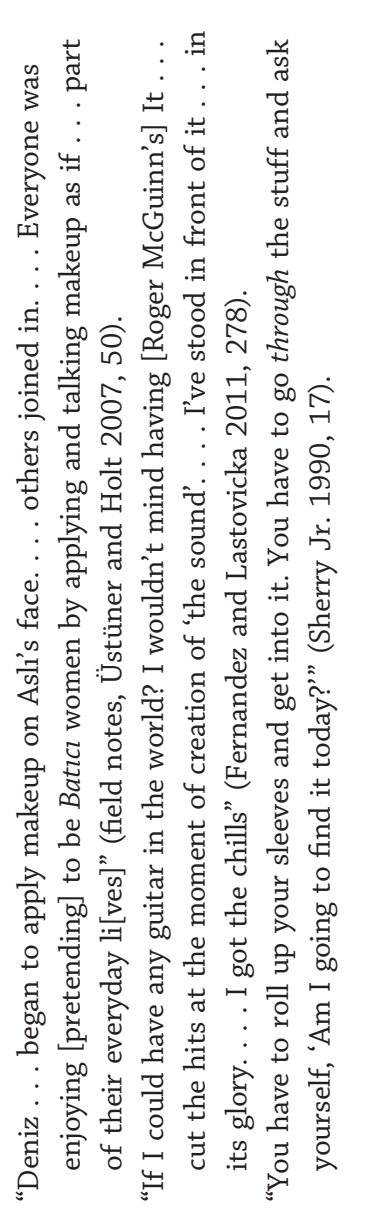

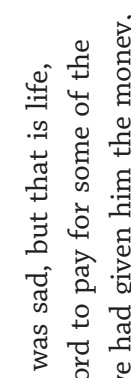

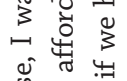

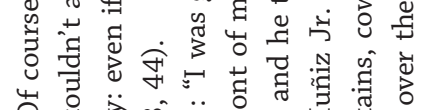

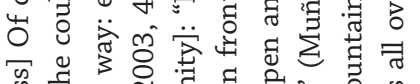

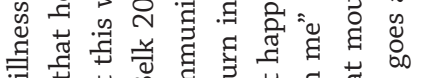

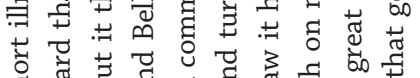

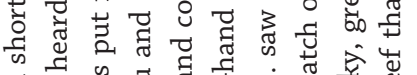

क

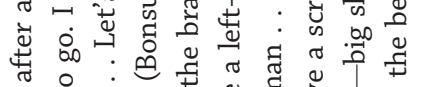

苟:

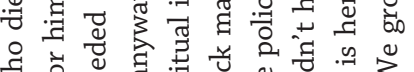

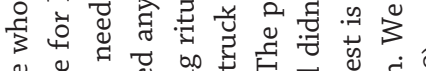

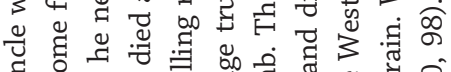

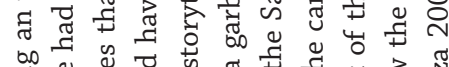

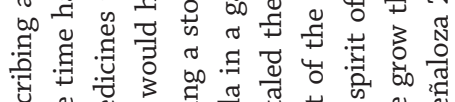

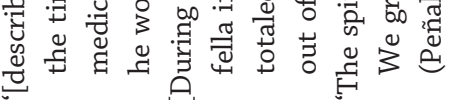

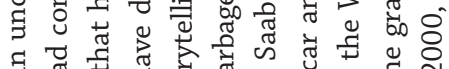

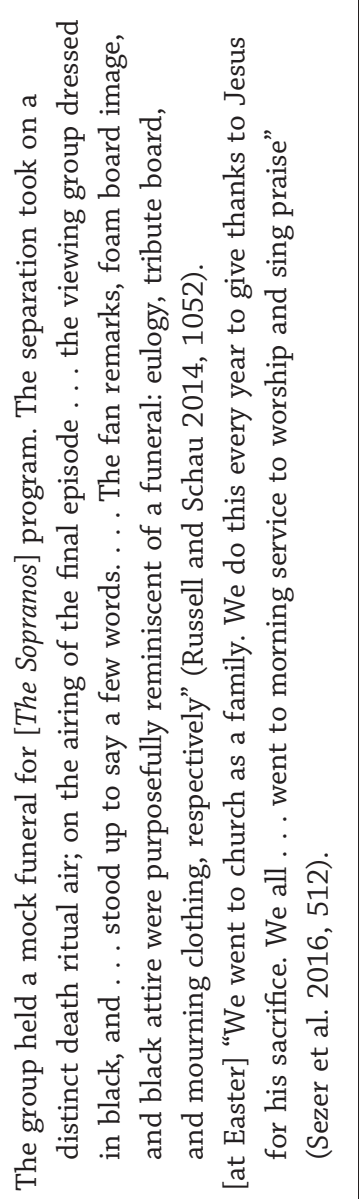

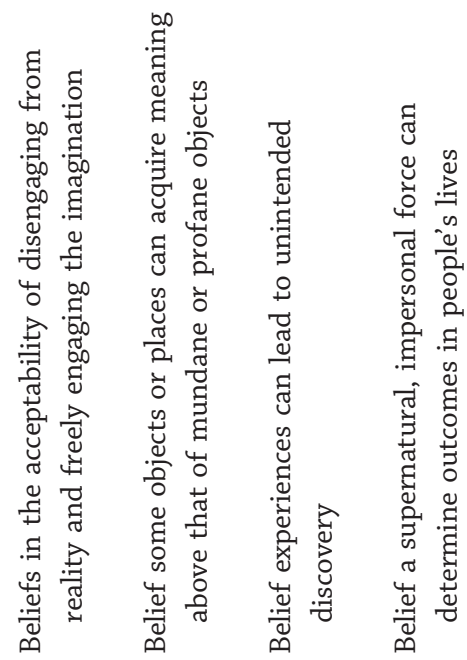
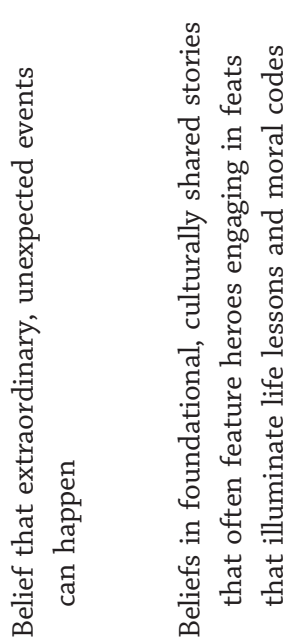

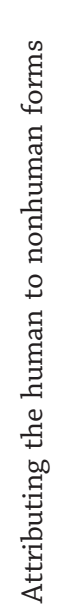

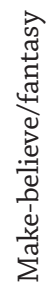

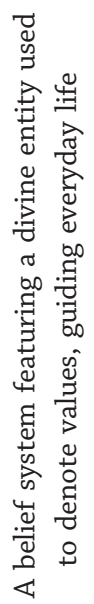

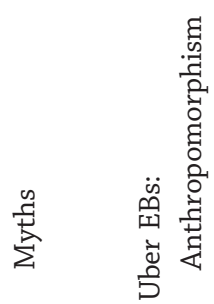

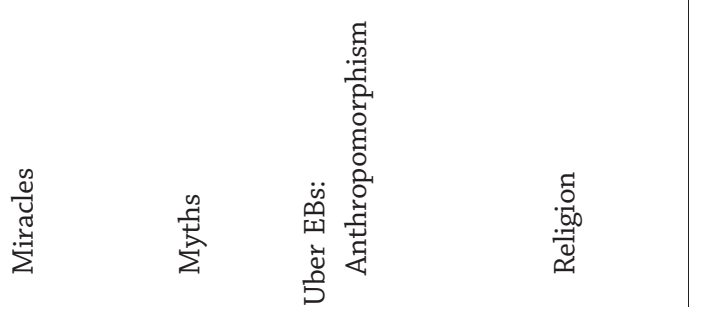


social system that liberates them from a less empathetic and economically driven capitalist system. However, Kozinets (2002) reports that, in fact, the most prominent attendees of Burning Man receive the best festival sites because they pay premium prices for them. In addition, the following excerpt reveals consumers may even articulate the irrationality of ascribing to the EB of self-transformation, especially in risky consumption contexts (Arnould and Price 1993, 40 41):

For me, river rafting is a horrible thing. I am scared to death of water. . . . I never felt safe, but I did start to feel like I wasn't in complete danger. For the first 15 to 20 minutes it was pure terror. . . . By the end of the day I'd been thrown all over the raft, I was soaking wet, I was very drained because I'd been tense all day long, but I felt very invigorated . . . it is challenging, exciting, thrilling, exhausting, and I'd recommend it highly.

Superstition. Kramer and Block $(2008,784)$ adopt the definition of superstition as "beliefs . . inconsistent with the known laws of nature or with what is generally considered rational in a society." People often engage in superstitious behavior when trying to manage stress, risk, uncertainty, and lack of perceived control (Block and Kramer 2009). Within ritual contexts, we find this especially true when consumers engage in what van Gennep (1960/2013) terms rites of passage, that is, occasions marking people's lifestage transitions from one social group to another. As a result, people may often experience desired and undesired identity shifts, at the individual and/or social levels.

All cultures incorporate at least three key rites of passage - birth, marriage, and death - and how these unfold can affect the social status not only of the focal participants but also of the social groups they occupy. For example, cross-cultural (Chinese and Vietnamese) couples in Nguyen and Belk's $(2013,529)$ study mull over how to honor (and not dishonor) the wedding-costuming traditions of each ethnic group. Superstition decisively shapes one couple's decision. The groom's relatives were against the couple changing from one set of costumes to another, as "they interpreted the act of changing clothes as a symbol for changing spouses. . . . The bride's family . . suggested [she] could change to [one costume] . . . and later be presented to the groom's relatives [in the other] . . . the relatives would not know she had changed."
Taboo. Schoemaker and Tetlock $(2012,8)$ note that cultures regard taboo entities as "consecrated, inviolable, forbidden, unclean, or cursed." This EB reflects consumers' perceptions that they consider certain phenomena either too sacred or too profane for ordinary human interaction. However, cultural norms may permit specific people (e.g., shamans) to manage and maintain these items. Anthropologists have long noted that taboos can help establish boundaries between sacred and profane domains, can reinforce identities, and can maintain social order. Our data set supports consumers' recognition of these functions. McAlexander et al. (2014) offer a negative case of taboo. A former Mormon congregant violates the Church's no-caffeine norm, noting the lack of negative consequences: "like the first time [I had] a cup of coffee . . . waiting, and kind of testing. 'Oh, I'm okay.' You know? Like nothing bad happened" (870).

\section{Enchanting EBs}

Enchanting EBs enable consumers to suspend disbelief in the rational world and engage in powerful or magnetic processes seemingly explainable only by magic. Perhaps not surprisingly, given that rituals are nonroutine (or even extraordinary) consumption experiences, our analysis supports several categories of enchanting EBs: "charisma," "make believe/fantasy," "nature worship," "sacredness," and "serendipity."

Charisma. Consumers for whom charisma is salient acknowledge that specific people possess exceptional qualities that imbue them with a magical and powerful aura; this phenomenon in turn helps them attract followers (Dion and Arnould 2011, 503). Thus, while most EBs pertain to people's relationships with objects and/or places, charisma reflects enchantment by a person. Research acknowledges the importance of charismatic leaders of rites and ceremonies whom participants revere because these leaders possess an endowed, singular status and special knowledge (Belk, Wallendorf, and Sherry Jr. 1989). Our analysis affirms consumers' beliefs in the power of shaman-like individuals in contemporary rituals (e.g., disc jockeys at clubs; Goulding et al. 2009). Likewise, field notes from Arnould and Price $(1993,35)$ aver consumers' reverence for river rafting guides: "It's real clear that Jeff [a guide] made an impact on people... [who] would come up to him and say, 'You made this trip for me."”

Nature Worship. Belk and Costa (1998, 234) discuss nature worship as "evoking and invoking a quasi-religious 
naturalism involving reverence for the mountains and nature." In a similar vein, Arnould, Price, and Otnes (1999, 59) underline the power of nature in consumers' river-rafting experiences, noting the "putative ancestors connected with the wildness landscape ... and ancient ecological and geological forces." Nature worship thus transcends what these authors describe as the "rationalistic logic" (60) pervading everyday life. Likewise, Canniford and Shankar (2013, 1052) identify "sacred nature" in their ethnography on surfing, highlighting the affective and perceptual elements of nature worship (see example in table 2). These studies support consumers' beliefs that nature can be a source of ambivalence, awe, delight, enchantment, restoration, and wonder.

Make-Believe/Fantasy. Martin $(2004,137)$ denotes fantasy as involving an "unfettered freedom of expression beyond ... what is known and believed," and a "break from established reality." Building on Cohen and Taylor (1992), Belk and Costa (1998) detail how fairy tales, adventure, romance, and heroes enrich consumer fantasies. Relatedly, Schouten (1991) illustrates how fantasy resonates with consumers' choices to have plastic surgery. One informant describes how she plays "character roles" in her life but hopes to be the "romantic lead" after surgery: "if I were in The Wizard of $\mathrm{Oz}$. . . I would be . . . one of the Munchkins rather than Dorothy... sort of on the sideline . . I've had fantasies, but that's all they ever were" (Schouten 1991, 418). Our analysis also supports St. James, Handelman, and Taylor's (2011) assertion that consumers gain agency when engaged in make-believe-for example, by controlling how ludic activities unfold when people adopt the personae of characters in role-play games (Martin 2004).

Sacredness. Sacredness reflects people's beliefs that objects, people, or places on the earthly plane can attain singularized status, that is, understood as rising above the status of everyday objects (Belk et al. 1989). Marshall (2010) asserts sacredness is "superimposed upon an object by some observer(s) and as such, [is] a property of ... observers rather than . . objects." Sacredness also reflects the EB that entities can be contagious - that is, their positive or negative potency can transfer to proximal entities, people, or events (Belk et al. 1989).

Belk et al. (1989) plumb the linkages between sacredness and the processes that reinforce singularized statuses of object or people and note one way that consumers instill and maintain this EB is by enacting and engaging in key sacralizing rituals. Fernandez and Lastovicka's (2011) work on consumer fetishes - a specific type of sacredness-demon- strates people will even imbue replicas (e.g., facsimiles of famous musicians' instruments) with sacred qualities and then assert that the owners' auras radiate from these replicas.

Serendipity. Dew $(2009,735)$ defines serendipity as "search leading to unintended discovery." This EB opens people to fortuitous encounters, even as serendipitous outcomes prove to be "elusive, unpredictable and ... not subject to control" (Foster and Ford 2003, 321). Paradoxically, consumers adhering to serendipity often engage in highly agentic behavior. For example, Sherry Jr.'s swap-meet participants describe engaging in "treasure hunting"; although they are unsure what they will find, they believe the items they are destined to own will magically reveal themselves. Furthermore, this EB appears in high relief when it is unfulfilled. After searching for her wedding-dress, one bride notes ruefully, "I never felt ... I actually found the dress ... you keep trying . . . and ... expect to have that 'perfect dress' feeling ... that was disappointing" (Otnes, Lowrey, and Shrum 1997, 85).

\section{Explaining EBs}

Explaining EBs help consumers make sense both of their immediate worlds and those they have yet to experience. "Fatalism," "miracle," and "myths" emerge as three explaining EBs in ritual contexts.

Fatalism. Fatalism reflects people's belief that "a mysterious force, generated and directed by an impersonal transcendental power or law" directs their lives (Pepitone 1997, 256). Fatalism does not require support by a religious belief system that involves people attributing outcomes to the actions of deities or higher powers (Fischer et al. 2007). Yet it does involve recognizing that some supernatural power intervenes to determine life outcomes; thus, people who adhere to fatalism typically disavow belief in their own agency. Importantly, fatalism is not necessarily associated with negative consequences. In Fischer et al. (2007, 436), one woman who had used assisted reproductive technologies reveals she ultimately conceived her daughter naturally, explaining "the time was just better for us ... I think it had much more to [do] with it than just relaxing. ..."

Miracle. Miracles are "effect[s] or extraordinary event[s] in the physical world [surpassing] known human or natural powers and . . . ascribed to a supernatural cause" (MerriamWebster 2018). Historically, people attributed miracles to divine beings within religious systems. However, Belk et al. 
$(1989,9)$ note modern societies typically replace "the miracles of god and nature ... by scientific explanations." In ritual contexts, consumers often describe miraculous revivals of products (e.g., Apple Newton batteries restarting; Muñiz Jr. and Schau [2005] canceled TV programs picked up other networks; Russell and Schau [2014]). These examples reveal two key points. First, this EB may emerge only after consumers experience a miracle, rather than because they adhered to an a priori belief that a miracle might happen. Second, like serendipity, marketplace-mediated miracles may require consumers to exert focused efforts themselves (e.g., tinkering with products; staging write-in campaigns to save programs). Thus, this EB may involve both consumers' agentic activities and their delighted disbelief that these activities, in conjunction with some action stemming from the marketplace, lead to a seemingly miraculous outcome.

Myths. A myth is a "foundational story or a system of related stories" (see Cayla and Arnould 2008, 99). We find support for these authors' assertion that myths feature culturally shared heroic figures who offer meaning to life and embody social codes of conduct. For example, Belk and Costa (1998) find mountain-man reenactors discuss their reverence for early settlers in the Western United States. One states, “I mean, if it weren't for [mountain men], the West would have never been opened up. Because they came out and [blazed] a trail the ordinary settler never would have done" (236). Beliefs and values rooted in self-reliance and hard work underpin American culture and transfer from generation to generation as individuals interpret their own histories. A visitor to a Western trade show "spoke of being seduced by the myth of the West"; another "noted that though ranching departs from the John Wayne version, in that its conformity goes against the myths of freedom and individualism, he would not live anywhere else" (Peñaloza 2000, 98).

\section{Uber EBs}

We find strong emic support for the assertion that two EBs in our data set merit the label of "uber EBs," in that they support all four functional tropes we identify above: connect, control, enchant, and explain.

Anthropomorphism. Aggarwal and McGill $(2007,468)$ detail anthropomorphism as "seeing the human in nonhuman forms." They offer examples from consumer contexts where people attribute human physical traits or personalities to brand mascots (e.g., Tony the Tiger) or brands. Within ritual contexts, we find support for Guthrie's (1993) assertion that people engage in anthropomorphism for myriad reasons. First, as Hirschman (1994) explains, people anthropomorphize their domestic animals for comfort and companionship and reinforce these connections through events such as pets' birthday parties. In addition, people leverage this EB to make sense of phenomena they do not understand, as reflected in an Apple Newton brand-community member's ritual storytelling about the brand (Muñiz Jr. and Schau 2005, 741-42):

I left the Newton 2000 on the roof of the car . . . I took off really fast and the poor thing went . . . all over the road. With the batteries and tray flying one way, the PC cards and lid the other way and the Newton just scraping across the ground, I almost died. I pulled over ... picked up all the pieces and attempted to put them back [where] they went. Surprisingly, everything was okay. . . . It's almost like the Newton knew how important the stuff inside it was. It's still ticking!

Finally, consumers' reliance on this EB enables them to enhance predictability in ritual situations. One surfer describes his relationship with the ocean: "I'll expend a lot of energy getting to that spot ... I think that the ocean notices ... and will hopefully, give me some really good waves" (Canniford and Shankar 2013, 1055). Given the growing evidence that anthropomorphism is key to many types of consumption (Kim and McGill 2011; Aggarwal and McGill 2012), perhaps it is unsurprising that this EB fulfills so many functions in ritualistic contexts.

Religion. Schmidt et al. (1999, 10; Mathras et al. 2016) define religion as "systems of meaning embodied in a pattern of life, a community of faith, and a worldview that articulate a view of the sacred and of what ultimately matters." These elements emerge as foundational to the examples of religion in our data set as well. O'Guinn and Belk (1989) highlight how the institutionalized beliefs associated with Christian fundamentalism support consumers' interpretations of visits to Heritage Village, USA, as enchanting: "It's like you come into a whole different world. . . . It's an oasis. You can talk to people here about anything but not in the 'real' world ... [where] everybody makes fun of [Christians]" (231). This EB also helps consumers feel connected to likeminded believers and even to nonbelievers as well (e.g., if beliefs spur evangelical work; McAlexander et al. 2014). 
An example from Bonsu and Belk $(2003,44)$ aptly captures how religion can incorporate all four functions EBs can fulfill:

When someone dies, he is not quite dead. We need them [ancestors] to protect us [Explain]. Death brings an end to all of the pain and ... [creates] the power to help us [Enchant]. We should be happy for the dead. We should help them as best as we can even after they leave us ... what better way to make them happy than to recognize their presence and to pour libation to them every now and then? . . . They are all around us because Onyankopon Kwame [God Almighty] has made it so [Connect]. We have to respect the ancestors so that we can all live together in peace [Control].

\section{HOW EBS SHAPE CONSUMERS' RITUAL PARTICIPATION}

In this section, we discuss another aspect of the functionality of EBs - namely, how they shape consumers' participation in stages of the ritual process. To address this question rigorously requires focused research not found in the consumer behavior canon, and that would specifically explore the temporal nature of rituals within and between contexts. Relatedly, our sample contains fewer instances of data than those supporting our first research question. Thus, we present this analysis as grounded research propositions to guide future research. We find support for three propositions. Each addresses how EBs shape behavior before, during, or after ritual participation. Table 3 provides additional examples from our data set for each proposition.

Proposition 1: Consumers leverage EBs to legitimize their motivations to participate in rituals.

Suchman $(1995,574)$ defines legitimacy as a "generalized perception or assumption that the actions of an entity are desirable, proper, or appropriate within some socially constructed system of norms, values, beliefs, and definitions." People rely on different sources of legitimacy from within broader cultural institutions and activities to justify their beliefs and actions. We find EBs help legitimize consumers' motivations to engage in ritual behavior, usually by providing moral authority or cultural support. For example, Vikas, Varman, and Belk (2015) highlight how uppercaste Hindus draw from purifying religious rituals to legitimize power displays and maintain their social status, even as contemporary market forces are disrupting traditional social structures. In that instance, the EB of religion provides the moral authority to motivate these consumers' ritual behavior. Likewise, Schouten's (1991) informants draw on the EBs of self-transformation and make-believe to justify opting for high-cost and potentially dangerous surgery. Conceptualizing this purchase as a rite of passage to which they are entitled, informants turn to culturally supported ideals to justify their decisions. Through fantasies of romance and transformation, Leslie ponders how plastic surgery would enable her to be "Cinderella," with her "fairy godmother offering her a nose job!" (Schouten 1991, 418).

Several studies in our sample reveal consumers also leverage EBs to legitimize participating in family rituals. For example, the Erikson family in Epp and Price (2010, 831) singularizes a kitchen table that serves as a legitimate site for these events. Clearly motivated by the EB of nostalgia, one family member explains:

My mom entertained a lot ... host[ing] wedding and baby showers. . . . It was very much . . . a celebration table. . . . This would have been the first year . . . I had a back-to-school coffee without the table. That would have really made me sad, so I had Reece and Rex [Reece's father] ... put [the table] together for the ... coffee.

Proposition 2: Consumers leverage EBs to facilitate their ritual enactments.

We also find EBs can sustain and anchor consumers when they engage in ritual enactments. Hirschman's (1994) informants anthropomorphize pets as family members through nightly walks, meal preparation, sleeping together, and calendrical celebrations. Broadly speaking, then, the uber EB of anthropomorphism provides a cognitive and emotional scaffold for the time, money, and effort people devote to pet rituals. Likewise, Fischer et al. (2007, 436) find informants' EBs lead them to singularize objects rooted in religion or mysticism, believing these can increase chances of success for medical outcomes. Lisa takes these objects with her while undergoing an in vitro fertilization (IVF) egg transfer:

One girlfriend got me a fertility frog ... [others] gave me . . . little angel pins. . . . I had my own rosary beads. . . . Then my other girlfriend gave me . . . a little [Buddhist] stone. . . . I carried everything around for a month. ... On the day of the transfer ... I had 


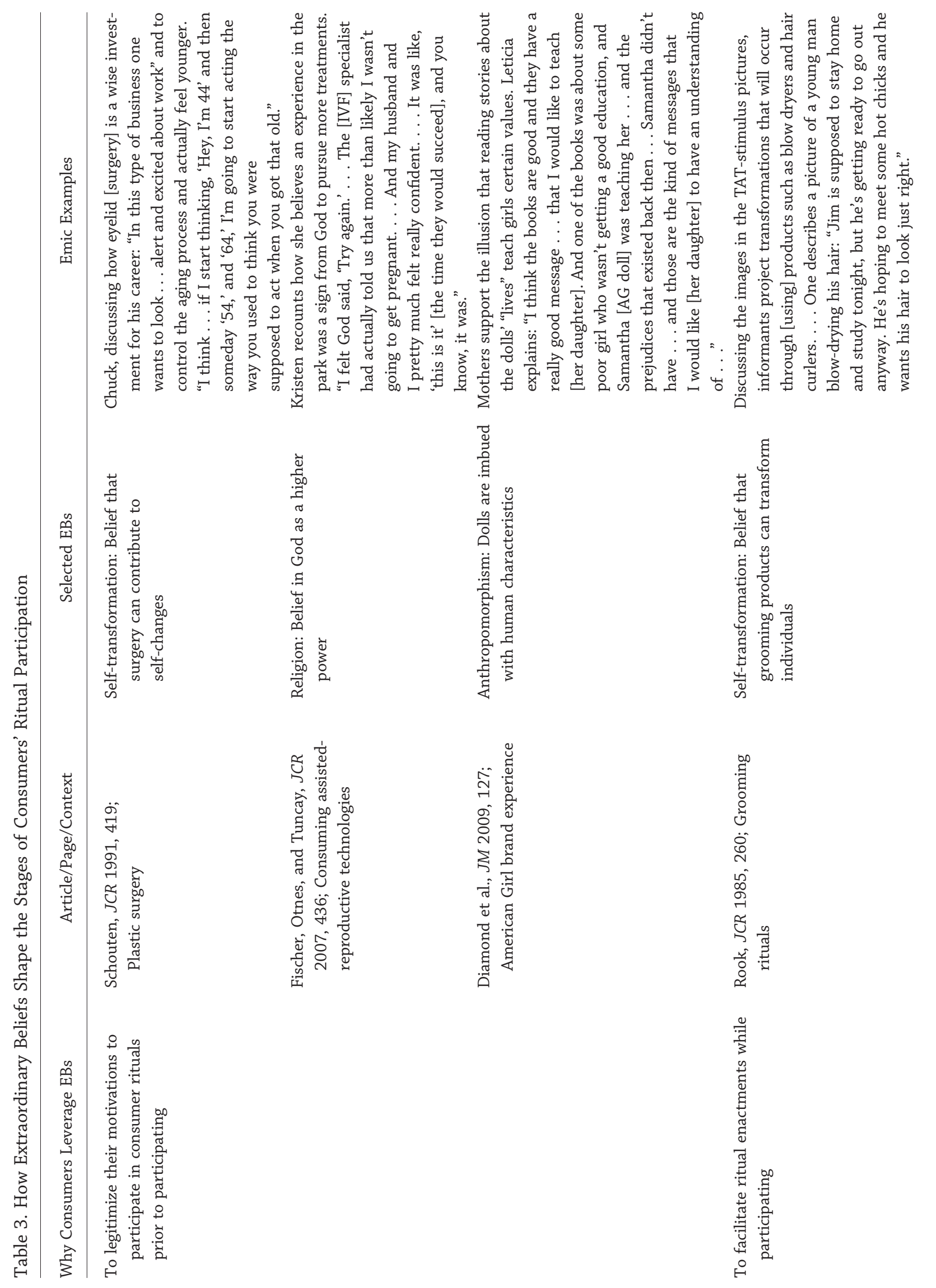




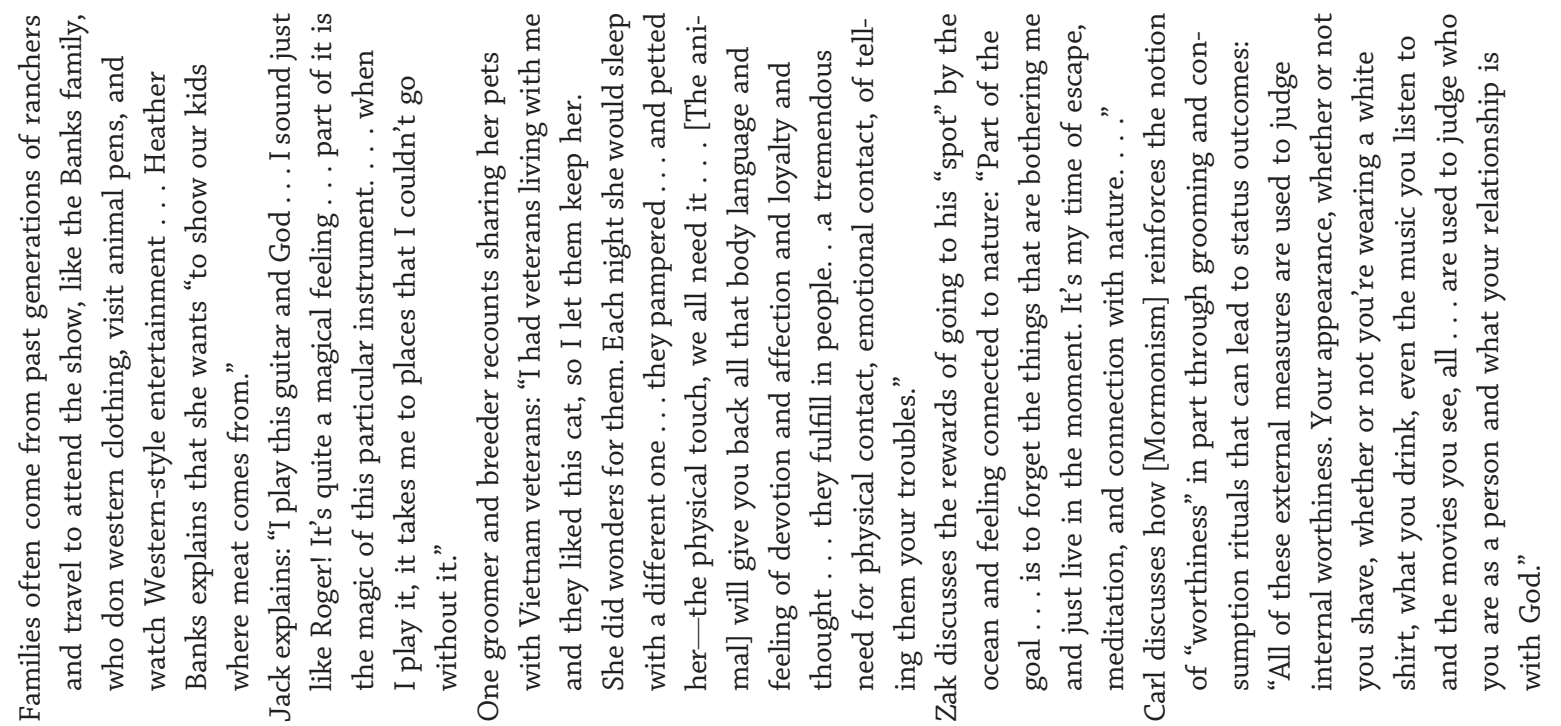
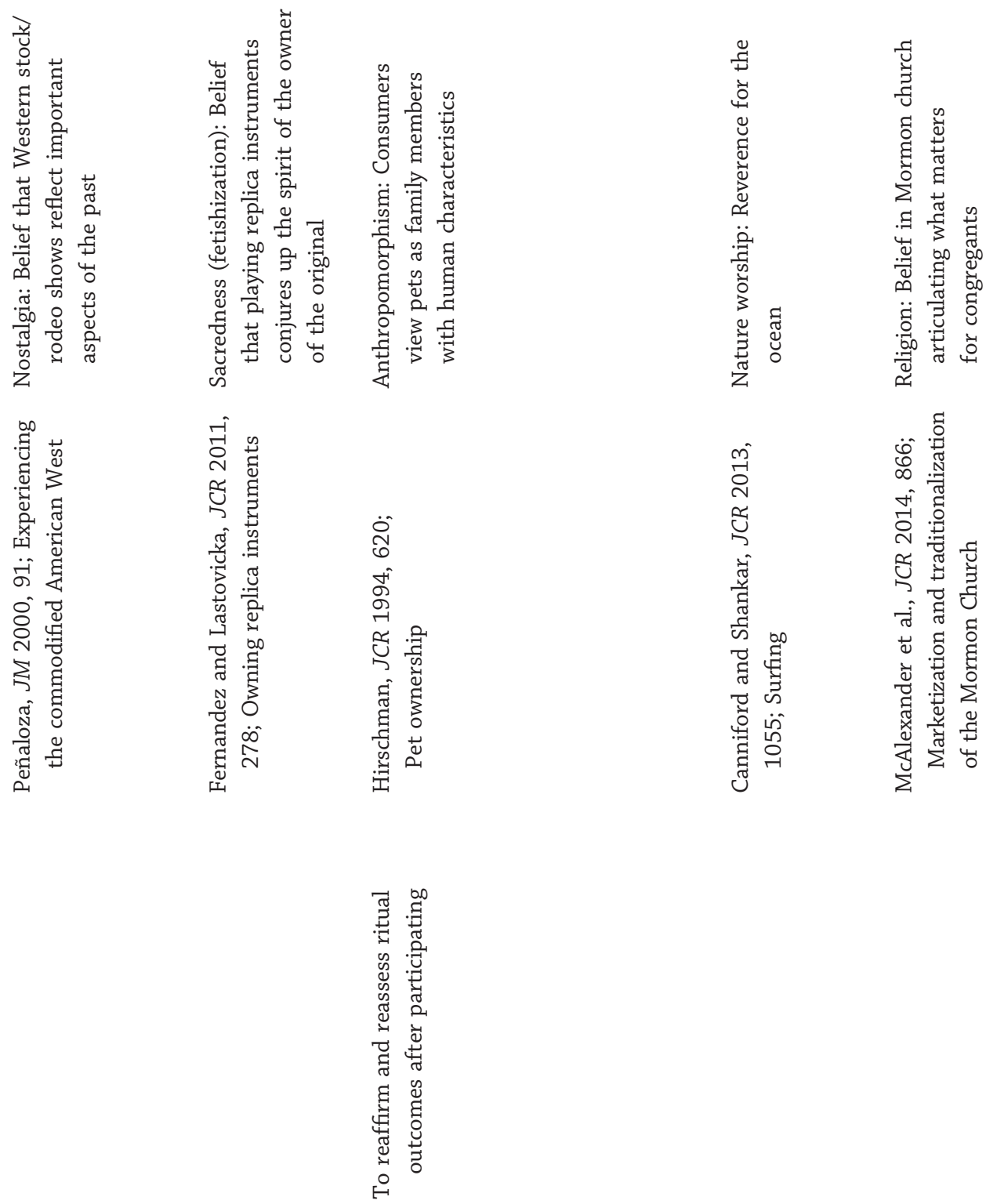
[everything] in my hand ... [and] ... told the nurses, "I have all these spirits with me . . and I'm going to have a baby."

Proposition 3: Postritual, consumers leverage EBs to reaffirm or reassess outcomes.

Our final proposition asserts that consumers leverage EBs to assess the efficacy of post-ritual outcomes. Our data offer fewer insights on this topic than on the propositions above. Nevertheless, we find evidence that consumers leverage EBs to assess how rituals can enhance their lives hedonically and cognitively. Such EBs contribute to consumers' perceptions that rituals can provide community, emotional release, play, transformation, status, meaning, order, and structure. These outcomes further encourage people to re-engage in rituals; sometimes, these can become regular occurrences, and perhaps even traditions. For example, one couple in Nguyen and Belk $(2013,528)$ struggled with whether to honor certain customs in their wedding, recognizing the potential damage to family harmony if they did not. Ultimately, the groom reflected on their decision to adhere to the EB of sacredness and incorporate these expected practices into their wedding:

At first, I did not like the customs. It's not because my parents wanted that I must do it. I have my own point of view. I talked to the elders. I read from books and the Internet. When I understood the meanings ... I thought it is necessary to follow the customs. I am happy and my parents are happy as well. ... When I have children, I want to keep those traditions in their wedding.

Likewise, people may lean on EBs to justify postritual emotions. St. James et al.'s $(2011,640)$ study of weight loss finds informants anthropomorphize forbidden foods (e.g., "Aged English or New York cheddar . . . sings love songs in my ear") to justify their regretful surrender to temptation. Yet tying this failure to an EB helps minimize feelings of guilt and self-hatred-emotions that could thwart participation in further weight-loss rituals, such as self-denial of food.

\section{FUTURE RESEARCH AND LIMITATIONS}

We believe our typology of EBs (and the functional tropes that they illuminate) elicit myriad intriguing questions that future research can explore. First, the emic examples found in our sample of articles depict consumers' experiences with rituals before, during, and after these events. However, it is also the case that prior to engaging in these activities, consumers might not acquire or ascribe to EBs. Consider someone who hits a home run in a baseball game and decides that from then on, he/she/they will only play with the "lucky bat" that "caused" the run. Thus, one question worth exploring is, how do consumers actually acquire and ascribe to EBs during various stages of consumer rituals (or other types of consumption experiences)?

Second, we find that in ritual contexts most EBs fulfill one function each; however, it is also true that several EBs often are salient in a context. Furthermore, one EB may spur elicitation of another, illuminating a "cascading" effect similar to what Otnes, Ruth, and Crosby (2014) find when consumers engage in transformative consumption experiences. For instance, some informants in Arnould and Price (1993) first engage in nature worship and then anthropomorphize nature. Then they may unexpectedly find that these new and deep connections with nature lead them to form beliefs about transforming their lives to be more nature-based. Thus, researchers could explore whether and how EBs emerge simultaneously or sequentially in complex and prolonged consumption contexts.

A third important topic for future research emerges in the intriguing negative cases of EBs in our data. Specifically, what happens when rituals fail? Consider the disappointed bride whose desire for the "perfect dress feeling" (Otnes et al. 1997, 85) goes unfulfilled. Specifically, how resilient are EBs in the face of consumer or marketplace failures? Does the resilience of a particular EB depend on factors such as its strength, salience, and shifts in cultural support systems? For example, Üstüner and Holt (2007, 52) note: "Myths are fragile constructions. When the distance between the myth's ideals and the reality of everyday life becomes too large, the myth's ritual power to make the imagined real comes unglued." In addition, how do marketplace stakeholders such as service providers help bolster or block these EBs? What can researchers learn about the resilience of EBs, rituals, consumers, and producers in the face of rituals gone wrong?

Fourth, our review of the literature demonstrates the need for a holistic study of one or more consumer-ritual contexts that specifically focus on understanding the who, what, when, where, and how of EBs in these contexts. Conducting a longitudinal study on this topic would undoubtedly provide much more nuanced understandings of these questions and enable the development of theoretical frameworks that 
could emplace the role of EBs as antecedents, concurrent influences, or post hoc elements in consumers' ritual experiences. Relatedly, rituals can occur on micro-, meso-, marketplace, and macrolevels. Thus, we might expect different types of EBs to emerge, depending on the structural origin and most salient level of the ritual, the shared understanding and support for EBs among participants, and the cultural stability of various consumer rituals. For example, people's EBs about weddings may be more or less influential on the actual ceremony and accompanying subrituals. Consider a nature-worshipping couple that wants to hold an entirely ecologically friendly wedding, but whose families hold firm beliefs about the sacred nature of more traditional wedding variants. Likewise, meso-level structures may support or stifle EBs (e.g., a bride with two friendship groups may find one supports the occasion as her "one day to be a princess," while another group takes a feminist stance and eschews this interpretation). Thus, researchers could explore how factors emanating from these strata shape the role of EBs in ritual (or non-ritual) contexts.

Finally, our analysis clearly demonstrates that EBs may motivate consumers' ritual participation. However, the literature is virtually silent on how EBs may shape marketers' roles in creating consumption experiences. The recent Supreme Court case involving the baker who declined to make a wedding cake for a gay couple based on what he argued to be his sincere religious beliefs indicates that marketers acknowledge their EBs can influence their commercial practices (Liptak 2018). Furthermore, Arnould and Price (1993) find river guides allude to their own EBs of nature worship and superstition as shaping the ways they create riverrafting experiences for their clients. Similarly, marketers may serve as shamans for consumer experiences and brands, as Dion and Arnould's (2011) study of fashion designers attests. Thus, how EBs shape the actions of marketing stakeholders, and how these in turn affect consumer behavior and consumer welfare, are worthy topics to explore.

\section{Limitations}

Our article focuses on extraordinary beliefs (EBs) that manifest in the context of consumption rituals. We recognize that the overriding functions of EBs in nonritual contexts may differ than the ones we identify. Therefore, we encourage researchers to examine EBs in a wider range of experiential and nonexperiential contexts, to expand our understanding (and likely the typology) of EBs salient to consumer behavior. In addition, as noted, we limit our sample to articles on ritu- als appearing in top marketing journals. We could have broadened our search by including articles on ritualistic consumption in other publications and by including those exploring gift giving specifically. Conducting future research using either of these sources could enhance and build on our findings.

In conclusion, this article leverages emic examples of consumers' EBs in extant studies of ritualistic consumption that appear in top-tier scholarly publications, to construct a grounded typology of 15 EBs organized around four overriding functions. We hope that this typology proves useful to scholars interested in how EBs can shape consumption within ritual contexts and beyond.

\section{REFERENCES}

Aggarwal, Pankaj, and Ann L. McGill (2007), "Is That Car Smiling at Me? Schema Congruity as a Basis for Evaluating Anthropomorphized Products," Journal of Consumer Research, 34 (4), 468-79.

_ (2012), "When Brands Seem Human, Do Humans Act like Brands? Automatic Behavioral Priming Effects of Brand Anthropomorphism," Journal of Consumer Research, 39 (2), 307-23.

Arnould, Eric J. (1989), “Toward a Broadened Theory of Preference Formation and the Diffusion of Innovations: Cases from Zinder Province, Niger Republic," Journal of Consumer Research, 16 (2), 239-67.

Arnould, Eric J., and Linda L. Price (1993), "River Magic: Extraordinary Experience and the Extended Service Encounter," Journal of Consumer Research, 20 (1), 24-45.

Arnould, Eric J., Linda L. Price, and Cele Otnes (1999), "Making Magic Consumption: A Study of White-Water River Rafting," Journal of Contemporarv Ethnographv, 28 (1), 33-68.

Belk, Russell W. (1991), "The Ineluctable Mysteries of Possessions," Journal of Social Behavior and Personality, 6 (6), 17-55.

Belk, Russell W., and Janeen A. Costa (1998), "The Mountain Man Myth: A Contemporary Consuming Fantasy," Journal of Consumer Research, 25 (3), 218-40.

Belk, Russell W., Melanie Wallendorf, and John F. Sherry Jr. (1989), “The Sacred and Profane in Consumer Behavior: Theodicy on the Odyssey," Journal of Consumer Research, 16 (1), 1-38.

Beverland, Michael M., and Francis J. Farrelly (2010), "The Quest for Authenticity in Consumption: Consumers' Purposive Choice of Authentic Cues to Shape Experienced Outcomes," Journal of Consumer Research, 36 (5), 838-56.

Bhatia, Gauri (2015), "Wedding Planner Is a Must-Have for Upmarket Indian Weddings," CNBC, December 6, www.cnbc.com/2015/12/06 /wedding-planner-is-a-must-have-for-upmarket-indian-weddings.html.

Block, Lauren, and Thomas Kramer (2009), "The Effect of Superstitious Beliefs on Performance Expectations," Journal of the Academv of Marketing Science, 37 (2), 161-69.

Bonsu, Samuel K., and Russell W. Belk (2003), "Do Not Go Cheaply into That Good Night: Death-Ritual Consumption in Asante, Ghana," Journal of Consumer Research, 30 (1), 41-55.

Bradford, Tonya Williams, and John F. Sherry Jr. (2015), "Domesticating Public Space through Ritual: Tailgating as Vestaval," Journal of Consumer Research, 42 (1), 130-51. 
Canniford, Robin, and Avi Shankar (2013), "Purifying Practices: How Consumers Assemble Romantic Experiences of Nature," Journal of Consumer Research, 39 (5), 1051-69.

Cayla, Julien, and Eric J. Arnould (2008), "A Cultural Approach to Branding in the Global Marketplace," Journal of International Marketing, 16 (4), $86-112$.

Celsi, Richard L., Randall L. Rose, and Thomas W. Leigh (1993), "An Exploration of High-Risk Leisure Consumtion through Skydiving," Journal of Consumer Research, 20 (1), 1-23.

Cohen, Stanley, and Laurie Taylor (1992), Escape Attempts: The Theory and Practice of Resistance in Everyday Life, London: Routledge.

Decrop, Alain, and Christian Debaix (2010), "Pride in Contemporary Sport Consumption: A Marketing Perspective," Journal of the Academv of Marketing Science, 38 (5), 586-603.

Dew, Nicholas (2009), "Serendipity in Entrepreneurship," Organization Studies, 30 (7), 735-53.

Diamond, Nina, John F. Sherry Jr., Albert M. Muñiz Jr., Mary Ann McGrath, Robert V. Kozinets, and Stephanie Borghini (2009), "American Girl and the Brand Gestalt: Closing the Loop on Sociocultural Branding Research," Journal of Marketing, 73 (3), 118-34.

Dion, Delphine, and Eric Arnould (2011), "Retail Luxury Strategy: Assembling Charisma through Art and Magic," Journal of Retailing, 87 (4), $502-20$.

Driver, Tom (1991), The Magic of Ritual, San Francisco: Harper.

Epp, Amber M., and Linda L. Price (2010), "The Storied Life of Singularized Objects: Forces of Agency and Network Transformation," Journal of Consumer Research, 36 (5), 820-37.

Fernandez, Karen V., and John L. Lastovicka (2011), "Making Magic: Fetishes in Contemporary Consumption," Journal of Consumer Research, 38 (2), 278-99.

Fischer, Ellen, Cele C. Otnes, and Linda Tuncay (2007), "Pursuing Parenthood: Integrating Cultural and Cognitive Perspectives on Persistent Goal Striving," Journal of Consumer Research, 34 (4), 425-40.

Foster, Allen, and Nigel Ford (2003), "Serendipity and Information Seeking: An Empirical Study," Journal of Documentation, 59 (3), 321-40.

Gillis, John R. (1997), A World of Their Own Making: Myth, Ritual, and the Quest for Family Values, Cambridge, MA: Harvard University Press.

Goulding, Christina, Avi Shankar, Richard Elliot, and Robin Canniford (2009), "The Marketplace Management of Illicit Pleasure, Journal of Consumer Research, 35 (5), 759-71.

Guthrie, Stewart E. (1993), Faces in the Clouds: A New Theory of Religion, Oxford: Oxford University Press.

Hirschman, Elizabeth C. (1994), "Consumers and Their Animal Companions," Journal of Consumer Research, 20 (4), 616-32.

Holbrook, Morris B. (1993), "Nostalgia and Consumption Preferences: Some Emerging Patterns of Consumer Tastes," Journal of Consumer Research, 20 (2), 245-56.

Kim, Sara, and Ann McGill (2011), "Gaming with Mr. Slot or Gaming the Slot Machine? Power, Anthropomorphism, and Risk Perception," Journal of Consumer Research, 38 (1), 94-107.

Kimura, Junko, and Russell Belk (2005), "Christmas in Japan: Globalization versus Localization," Consumption Markets \& Culture, 8 (3), 325-38.

Kozinets, Robert V. (2002), "Can Consumers Escape the Market? Emancipatory Illuminations from Burning Man," Journal of Consumer Research, 29 (1), 20-38

Kramer, Thomas, and Lauren Block (2008), "Conscious and Nonconscious Components of Superstitious Beliefs in Judgment and Decision Making," Journal of Consumer Research, 34 (April), 783-93.
Leigh, Thomas W., Cara Peters, and Jeremy Shelton (2006), "The Consumer Quest for Authenticity: The Multiplicity of Meanings within the MG Subculture of Consumption," Journal of the Academv of Marketing Science, 34 (4), 481-93.

Liptak, Adam (2018), "In Narrow Decision, Supreme Court Sides with Baker Who Turned Away Gay Couple," New York Times, June 4, www.nytimes .com/2018/06/04/us/politics/supreme-court-sides-with-baker-who -turned-away-gay-couple.html.

Marshall, Douglas A. (2010), "Temptation, Tradition, and Taboo: A Theory of Sacralization," Sociological Theory, 28 (1), 64-90.

Martin, Brett A. S. (2004), "Using the Imagination: Consumer Evoking and Thematizing of the Fantastic Imaginary," Journal of Consumer Research, 31 (1), 136-49

Mathras, Daniele, Adam B. Cohen, Naomi Mandel, and David Glen Mick (2016), "The Effects of Religion on Consumer Behavior: A Conceptual Framework and Research Agenda," Journal of Consumer Psychology, 26 (2), 298-311.

Mauss, Marcel (1950/2005), A General Theory of Magic, London: Routledge. McAlexander, James H., Beth Leavenworth Dufault, Diane M. Martin, and John W. Shouten (2014), "The Marketization of Religion: Field, Capital, and Consumer Identity," Journal of Consumer Research, 41 (3), 858-75.

McCracken, Grant (1986), "Culture and Consumption: A Theoretical Account of the Structure and Movement of the Cultural Meaning of Consumer Goods," Journal of Consumer Research, 13 (1), 71-84.

(2008), Transformations: Identity Construction in Contemporary Culture, Bloomington: Indiana University Press.

Merriam-Webster (2018), "Faith," Merriam Webster's Dictionary, https:// www.merriam-webster.com/dictionary/faith.

- (2018), "Miracle," Merriam Webster's Dictionary, https://www merriam-webster.com/dictionary/miracle.

_ (2018), "Transformation," Merriam Webster's Dictionary, https:// www.merriam-webster.com/dictionary/transformation.

Muñiz, Albert M., Jr., and Thomas C. O'Guinn (2001), "Brand Community," Journal of Consumer Research, 27 (4), 412-32.

Muñiz, Albert M., Jr., and Hope Jensen Schau (2005), "Religiosity in the Abandoned Apple Newton Brand Community," Journal of Consumer Research, 31 (4), 737-47.

Nguyen, Thuc-Doan T., and Russell W. Belk (2013), "Harmonization Processes and Relational Meanings in Constructing Asian Weddings," Journal of Consumer Research, 40 (3), 518-38.

O'Guinn, Thomas C. and Russell W. Belk (1989), "Heaven on Earth: Consumption at Heritage Village, USA" Journal of Consumer Research, 16 (2), 22738

Otis, Laura P., and James E. Alcock (1982), "Factors Affecting Extraordinary Belief," Journal of Social Psychology, 118 (1), 77-85.

Otnes, Cele, Tina M. Lowrey, and L. J. Shrum (1997), "Toward an Understanding of Consumer Ambivalence," Journal of Consumer Research, 24 (1), 80-93.

Otnes, Cele C., Julie A. Ruth, and Elizabeth Marie Crosby (2014), "ProductAgency Benefits: Consumer Perspectives and Strategic Implications," European Journal of Marketing, 48 (5), 878-98.

Peñaloza, Lisa (2000), "The Commodification of the American West: Marketers' Production of Cultural Meanings at the Trade Show," Journal of Marketing, 64 (4), 82-109.

Pepitone, Albert (1997), "Nonmaterial Beliefs: Theory and Research in Cultural Social Psychology," in The Message of Social Psychology: Perspectives on Mind in Society, ed. Craig McGarty and S. Alexander Haslam, Cambridge, MA: Blackwell, 252-67. 
Research and Markets (2017), "Global Beauty and Personal Care Products Market Forecast 2017-2023," BusinessWire, January 3, www.businesswire .com/news/home/20170103005748/en/Global-Beauty-Personal-Care -Products-Market-Forecast.

Rook, Dennis W. (1985), "The Ritual Dimension of Consumer Behavior," Journal of Consumer Research, 12 (3), 251-64.

Russell, Cristel Antonia, and Hope Jensen Schau (2014), "When Narrative Brands End: The Impact of Narrative Closure and Consumption Sociality on Loss Accommodation," Journal of Consumer Research, 40 (6), 1039-62.

Schau, Hope Jensen, Albert M. Muñiz Jr., and Eric J. Arnould (2009), "How Brand Community Practices Create Value," Journal of Marketing, 73 (5), 30-51.

Schmidt, Roger, Gene Sager, Gerald Carney, Julius F. Jackson, Kenneth J. Zanca, and Albert C. Muller (1999), Patterns of Religion, Belmont, CA: Wadsworth.

Schoemaker, Paul J. H., and Philip E. Tetlock (2012), “Taboo Scenarios: How to Think about the Unthinkable," California Management Review, 54 (2), 5-24.

Schouten, John W. (1991), "Selves in Transition: Symbolic Consumption in Personal Rites of Passage and Identity Reconstruction," Journal of Consumer Research, 17 (1), 412-25.

Scimago Lab (2018), "Scimago Journal and Country Rank," www.scimagojr .com/journalrank.php?category-1406

Scott, Rebecca, Julie Cayla, and Bernard Cova (2017), "Selling Pain to the Saturated Self," Journal of Consumer Research, 44 (1), 22-43.

Seaver, Maggie (2017), "The National Average Cost of a Wedding Hits $\$ 35,329$," The Knot, www.theknot.com/content/average-wedding-cost -2016 .
Sezer, Ovul, Michael I. Norton, Francesca Gino, and Kathleen Vohs (2016), "Family Rituals Improve the Holidays," Journal of the Association for Consumer Research, 1 (4), 509-26.

Sherry, John F., Jr. (1990), "A Sociocultural Analysis of a Midwestern American Flea Market," Journal of Consumer Research, 17 (1), 1330.

Spiggle, Susan (1994), "Analysis and Interpretation of Qualitative Data in Consumer Research," Journal of Consumer Research, 21 (3), 491503.

St. James, Yannik, Jay M. Handelman, and Shirley F. Taylor (2011), “Magical Thinking and Consumer Coping," Journal of Consumer Research, 38 (4), 632-49

Suchman, Mark C. (1995), "Managing Legitimacy: Strategic and Institutional Approaches," Academy of Management Review, 20 (3), 571610.

Turner, Victor, Roger D. Abrahams, and Alfred Harris (1966/2017), The Ritual Process: Structure and Anti-Structure, London: Routledge.

Üstüner, Tuba, and Douglas P. Holt (2007), "Dominated Consumer Acculturation: The Social Construction of Poor Migrant Women's Consumer Identity Projects in a Turkish Squatter," Journal of Consumer Research, 34 (1), 41-56.

van Gennep, Arnold (1960/2013), The Rites of Passage, London: Routledge.

Vikas, Ram Manohar, Rohit Varman, and Russell W. Belk (2015), "Status, Caste, and Market in a Changing Indian Village," Journal of Consumer Research, 42 (3) 472-98.

Wallendorf, Melanie, and Eric J. Arnould (1988), “'My Favorite Things': A Cross-Cultural Inquiry into Object Attachment, Possessiveness, and Social Linkage," Journal of Consumer Research, 14 (4), 531-47. 